\title{
Islamic International Law and the Right of Self-Defense of States
}

\author{
Abdul Ghafur Hamid @ Khin Maung Sein*
}

Islamic international law is a branch of the Shari' ah (Islamic law). Due to the classical doctrine of the notion of 'Jihad,' there have been misconceptions and Islam has been painted as a religion encouraging violence and war. This paper appeals for the reconsideration of the classical doctrine, which was adopted at a time when there was a state of war between Islamic and non-Islamic states. Going back to the roots and referring to the Qur' an and the Sunnah: the two primary sources of Islamic law, the paper argues that Islam prohibits aggressive war and that the essence of jihad' is 'self-defense.' After elaborating the essential conditions of the right of self-defense, the paper concludes that Islamic international law can contribute much to the present world order by providing moral and ethical values that modern international law is lacking.

\section{Keywords}

Shari ah, Self-defense, Jihad, Islamic International Law

\section{Introduction}

'Shari'ah' is an Arabic word meaning the path to be followed. It is the path not only leading to Allah,1 God Almighty, but believed by all Muslims to be the path shown by Allah, the Creator Himself. The Shari' ah, or Islamic law, is based on unqualified

* LL.B. (Yangon), LL.M. in International Law (Yangon), Ph.D. (IIUM), Professor of Law and Coordinator of the International Law and Maritime Affairs (ILMA) Research Unit of the International Islamic University Malaysia. The author may be contacted at: ghafur@iium.edu.my/Address: International Islamic University Malaysia P.O. Box 10, Kuala Lumpur 50728 Malaysia

1 'Allah' is the unique name used by Muslims of the God Almighty, the Lord of the Worlds, and the Creator of every living and nonliving thing in the entire universe. The term 'Allah' will be used throughout the article to refer to God Almighty. 
submission to the will of Allah and it embraces all aspects of life. Islamic international law is that part of Islamic law which deals with inter-state relations. Although the original idea of Islamic international law is peace, the Classical jurists used the word 'jihad' in a narrower sense and created the notion of a perpetual war between 'dar alIslam' and 'dar al-harb'. Detractors of Islam have almost exclusively focused on the warlike aspect of 'jihad.'

The reconsideration of the classical doctrine is imperative as all Muslim countries are now peaceful and active members of the international community and there is no state of war between Muslim and non-Muslim States. This fundamental change of circumstance calls for a new 'ijma' on the basis of the two primary sources of Islamic law: the Quran and the Sunnah. The relevant ayat from the Quran must be interpreted not in isolation but in their context and in the light of the background of the revelation. According to a number of modern Islamic scholars, such an interpretation clearly paves the way for the revival of the original idea that Islam prohibits aggressive war and that the essence of jihad is self-defense.

The paper categorizes self-defense into four types and elaborates the essential conditions of a lawful self-defense under Islamic international law. It concludes that Islamic international law can contribute much to the present world order by providing moral and ethical values that modern international law is lacking.

\section{Islamic International $\mathrm{Law}^{2}$ and the Doctrine of 'Jihad'}

Part of the Western misrepresentation of Islam was that Islam had no system of international law, no respect for treaties, no concept of human rights and no regard for the rights of neighbouring States. ${ }^{3}$

\section{A. Islamic International Law: Al-Siyar}

The truth is that the Islamic jurists developed a special branch of the Shari' ah, known as Al-Siyar, 4 to deal with questions of international law. Not many people will know that

2 Muhammad Tulaat Al Gunaimi, The Muslim Conception of International LaW and the Western Approach (1968); Muhamimad Haminullah, Muslim Conduct of State, (1977); Majid Khadduri, The Islamic Law of Nations: Shaybani's Siyar, (1966) [hereinafter Khaddur, The Islamic LaW of NATions].

3 C. G. Weeramamtry, Islamic Jurisprudence: An International Perspective 130 (1988).

4 The word 'Al-siyar' is the plural form of 'sirah', meaning 'conduct or behaviour'. The term Al-siyar was first used by Abu Hanifa, the founder of the Hanafi school. 
the world' s earliest treatises on international law as a separate topic were in fact Kitab Al-Siyar Al-Sagir and Kitab Al-Siyar Al-Kabir written by Muhammad Al-Shaybani in the $8^{\text {th }}$ century. Weeramantry acknowledges the fact that the Islamic scholars are pioneers in the early development of international law:

[W]ithin two centuries of the foundation of Islam there were already commentators and lecturers on Islamic international law. Among them were Abu Hanifa, the founder of the Hanafi School (699-767), Al-Shaybani (749-805), commonly regarded as the father of Islamic international law, and Al-Shafi' $\mathrm{i}$ (767-820), the celebrated founder of the Shafi' ite School. Al-Shaybani' s extensive treatise is perhaps the most detailed early work, while Shafi' i' s Kitab al-Umm contains an exposition of numerous principles of international law. 5

It is to be noted that these detailed works on international law were about 800 years earlier than that of Hugo Grotius who is generally regarded as the father of international law. The Dutch jurist published his work De jure belli ac pacis (On the Law of War and Peace) only in 1625, the time of the commencement of the Western international law. One of the main principles of Grotius was the proposition that treaties should be observed. This concept of pacta sunt servanda had long been a foundation stone of Islamic international law. The Messenger of Allah (peace be upon him) himself had set forth this principle and solemnly called upon Muslims to perform their treaties in good faith.

Among the most important contributions of Islamic international law were its definite rules on prisoners of war, protection of civilian populations, limitations of belligerent activities and reprisals, asylum, pardon, safe conduct, diplomatic immunity, negotiations and peace missions. 6

As Islamic international law is a component part of the Shari' ah, its sources are the same as that of the Shari' ah. The primary sources are the Qur' an and the Sunnah, and the secondary sources are the Ijma, and the Qiyas, both of which considered by many as methods of interpretation based on 'ijtihad' .7 The Qur' an is more authoritative than any book of statutes, for while statutes are the work of man, every word in the Qur' an is, for Muslims, the word of Allah, God Almighty. It provides for the Islamic world a single source of that higher law which stands above all other man-made laws. It is also to be noted that the Qur' an, as the word of God, is unchangeable. For the Muslim world, the Qur' an is unalterable and everlasting.

\footnotetext{
WERAMANTRY, supra note 3, at 132.

6 C. S. RHyne, InTERnAtional LAW 23-24 (1971).

7 AL GunaimI, supra note 2, at 106-119.
} 
It is, however, to be admitted that after the collapse of the Ottoman Empire, 8 the last empire ruled by Muslim sultans that lasted from 1299-1923,9 there has not been any more practical application of Islamic international law. ${ }^{10}$ The Muslim empire was replaced by a number of Muslim nation-states. These Muslim states have joined the United Nations and adhered to various international treaties. They are now part and parcel of the international community and do comply with contemporary international law together with their non-Muslim counterparts. As a result, Islamic international law is, like many other areas of the Shari' ah (Islamic law), largely dormant. Nevertheless, it does not mean that the study of the subject is of academic value only. The values, norms, and principles of Islamic law, in general, and Islamic international law, in particular, are deeply carved into the heart of every Muslim around the world, representing one-fifth of the entire world population.

\section{B. The True Meaning of Jihad}

The Arabic word 'jihad' does not mean 'war.' 11 It is derived from the verb "jahada' which means "to exert, to strive hard, or to make strenuous effort." 12 Its juridical meaning is "striving or exerting of one' s efforts in the cause of Allah." 13 Simply put, the essence of jihad is the exertion of one' s mental and physical energy in the cause of Allah by sacrificing one' s person, property, wealth and even life. It is entirely based on a true and sincere faith and earnest and ceaseless exertion in the service of Allah. Therefore, mere brutal fighting is opposed to the whole spirit of jihad, while the sincere scholar' s pen or preacher's voice or wealthy man's contributions may be the most valuable forms of jihad.

The jurists have distinguished four different ways in which the believer may fulfill his jihad obligation: by his heart, his tongue, his hands, and by the sword.14

8 The Ottoman conquest of Constantinople in 1453 cemented the status of the Empire as the preeminent power in southeastern Europe and the eastern Mediterranean. During this time, the Ottoman Empire extended its borders deep into Europe and North Africa.

9 Sean Krummerich, The Divinely Protected, Well-Flourishing Domain: The Establishment of the Ottoman System in the Balkan Peninsular, 30 The Student His. J. (1998-99).

10 The Ottoman sultans applied the Shari'ah as the law of the Empire and complied with the traditional Islamic international law principles of the payment of Jizya, the rights of Zimmis, and tolerance with other religious faiths. See Id.

11 The Arabic word for war is 'harb'; see FaruQI's Law Dictionary: Arabic-English 136 (1986).

12 See id. at 128; see also The Oxford English-Arabic Dictionary of Current Usage 406 (1981).

131 Fayruzabadi, QAmus AL-Munit 286 (Cairo, 1933), quoted in Khadduri, The Islamic LaW of Nations, supra note 2, at 55. Instead of the term 'In the cause of Allah', some commentators use terms such as 'In the path of Allah' or ' In the way of Allah'.

14 M. Khadduri, War And Peace in ohe LaW of Islam (1955), at 56. 
The believer may fulfill the jihad duty by heart in his efforts to combat the devil and to escape his persuasion to evil. This type of jihad, which may be called the 'spiritual jihad,' is so significant in the eyes of the Messenger of Allah (Peace be upon him). "The greatest jihad", says the Messenger of Allah (Peace be upon him), "is the fight against the evil passions of oneself." 15 The believer may fulfill jihad duty by his tongue and hands in his attempt to support the right and correct the wrong; and by the sword in taking part in actual fighting by sacrificing his life in the cause of Allah.16

In other words, the doctrine of jihad carries a twofold significance in Islam: the purely missionary activities of a Muslim and his defense of the Faith in a physical sense. The first duty - the duty to invite people to Islam - is a permanent duty laid upon all Muslims of all ages; while the second is a duty which arises upon contingencies. 17 The Holy Qur' an calls attention to both these duties in the clearest and most forceful words.

In the first place, the Qur' an speaks of a jihad to attain to Allah: "And those who strive in Our (Cause), We will certainly guide them to Our Paths." 18 Then it speaks of a jihad against unbelievers by means of the Holy Qur' an: “...but strive against them, with the utmost strenuousness, with the (Qur'an)." 19 The Prophet of Islam wages the "Iihadan Kabir-an" with the help of Allah's Revelation. Islam's greatest jihad is, therefore, not by means of sword, but by means of the Holy Qur' an, i.e., a missionary effort to establish Islam. 20

The Qur' an does not recommend war for propagation of Islam. Compulsion in religion is prohibited. Compulsory methods cannot be the means of inviting people to accept a faith. Belief is a matter of heart and its foundation is love and devotion. The following Qur' anic ayat clearly shows that jihad in the sense of war can never be a means of religious propaganda.

Let there be no compulsion in religion. Truth stands out clear from error. ${ }^{21}$

To you be your way, and to me mine.22

Invite (all) to the way of thy Lord with wisdom and beautiful preaching and argue

See 2 Maulana Fazlul Karim, MIshKat-Ul-Masabih 341.

16 Khadduri, WaR AND Peace, supra note 14, at 56 n.6.

17 Maulana Muhammad Ali, A Manual of Hadith 252 (1978).

18 Al-Qur'an, Surah al -'Ankabut 29: 69.

9 Al-Qur'an, Surah al -Furqan 25: 52.

20 The Holy Qur'an says: "Let there arise out of you a band of people inviting to all that is good, enjoining what is right, and forbidding what is wrong: they are the ones to attain felicity”. See Al-Qur'an, Surah Al 'Imran 3: 104.

21 Al-Qur'an, Surah al -Baqarah 2: 256 in part.

22 Al-Qur'an, Surah al -Kafirun 109: 6. 
with them in ways that are best and most gracious. ${ }^{23}$

If it had been thy Lord's Will, they would all have believed, - all who are on earth! Wilt thou then compel mankind, against their will, to believe?24

The second significance of jihad is to fight in the cause of Allah and to fight in defense of the Faith. This really is in the sense of the actual war. However, the essence of jihad is never an aggressive war; rather it is a defensive war, for no other ground but in the cause of Allah. The Holy Qur' an ordains:

To those against whom war is made, permission is given (to fight), because they are wronged; - and verily, Allah is most powerful for their aid - . (They are) those who have been expelled from their homes in defiance of right - (for no cause) except that they say: 'Our Lord is Allah.' ..." 25

By the phrase "against whom war is made", it is clear that permission to fight is given only when the other party has made an aggressive war. The essence of the military dimension of jihad is, therefore, self-defense. Jihad is the holy war in the sense that had there been no war, no religious liberty, no justice and no house of Allah would have been saved. The object of war is specified here as the deterrence of oppression, freedom of domicile, and freedom of faith. All the wars undertaken by the Messenger of Allah (Peace be upon him) and his companions were of this type.26 The Qur' an says in unmistakable terms about the object of war in another verse:

Fight in the cause of Allah those who fight you, but do not transgress limits; for Allah loveth not transgressors. 27

Here again, war is permissible only in self-defense in the cause of Allah; only to restore peace and freedom for the worship of Allah. In any case strict limits must not be transgressed: women, children, old and infirm men should not be molested, no trees and crops cut down, nor peace withheld when the enemy comes to terms. 28

Al-Qur'an, Surah Yunus 10: 99; see also Surah al -Nahl 16: 93; Surah al -Qasas 28: 56.

Al-Qur'an, Surah al -Hajj 22: 39-40 in part.

26 Maulana Fazlul Karim, supra note 15, at 339. See also Mahmud Shaltut (1893-1963, appointed Shaykh al-Azhar in 1958), AL-Qur'an Wa AL-QITAL (The Qur'an and Fighting), Cairo 1948, Jihad IN Medieval and Modern Islam 51 (1977), Shaltut writes that according to the Qur'anic ayat, there are three reasons for fighting, namely: to stop aggression, to protect the mission of Islam and to defend religious freedom.

27 Al-Qur'an, Surah al -Baqarah 2: 190.

28 Abdullah Yusuf Ali, The Meaning of the Holy QuR'an 76 n. 204 (1996). 
During the life time of the Messenger of Allah (peace be upon him), the military dimension of jihad meant resistance to aggression, in other words, self-defense. Nevertheless, the spiritual aspects of jihad were prevalent. This spiritual dimension was reflected in a hadith of the Messenger of Allah (peace be upon him) who, after returning from the battle of Badr, referred to war as the smaller jihad, in contrast to the struggle against oneself for piety or goodness, referred to as jihad ul-nafs, the greater jihad. Indeed much of the Qur'an and the Sunnah deal with how to reach a higher spiritual plane through iman (faith), 'aqida (belief), and taqwa (piety).

This is the original meaning of jihad. It is a Muslim's foremost duty, and the most excellent deed a Muslim can do. 29 The recompense would be the achievement of salvation, since jihad is the direct way to Paradise. The Qur' an says:

O ye who believe! Shall I lead you to a bargain that will save you from a grievous Penalty? - That ye believe in Allah and His Messenger, and that ye strive (your utmost) in the cause of Allah, with your wealth and your persons: That will be best for you, if ye but knew! He will forgive you your sins, and admit you to Gardens beneath which rivers flow, and to beautiful Mansions in Gardens of Eternity: that is indeed the supreme Achievement. 30

The conclusion, therefore, is that the true meaning of jihad is to strive hard (or to make strenuous effort) in the cause of Allah, that is, to fight against the evil passions of oneself to be able to maintain absolute obedience to Allah; to support what is right and to correct what is wrong according to the law of Allah; to invite people to Islam; and to fight in defense of the Faith against persecution and aggression.

\section{The Classical Doctrine of Jihad and Its Relevance in the Modern World Order}

The orientation towards peace and the limits on the resort to war shifted after the death of the Messenger of Allah (Peace be upon him) in response to the pressures of empire building and the dynamics of power. ${ }^{31}$ Muslim jurists of the eighth and ninth centuries found it expedient to legitimize the wars of expansion of the Muslim rulers. Therefore, their theories were the product of a historical epoch when the power of the Abbasid caliphate or the universal Islamic state, was at its zenith. It is not surprising that many of the Muslim jurists at that time based their argument on the

\footnotetext{
See SAHIH AL-BukHaRi, Muhammad Muhsin Khan (trans.), KitaB AL-JiHAD, Chapter 1, Ahadith 44, 45 and 46, (1983).

Al-Qur'an, Surah al - Saff 61: 10-13.

31 Abdullahi Ahmed An-Naim, Islamic Law International Relations and Human Rights: Challenge and Response, 29 CoRNELL INT'L L.J. 317, 322-24 (1987).
} 


\section{The notion that jihad is a permanent war against non-believers}

The idea of jihad was, and still is, the cause of the most common and prevalent misconceptions. Many western orientalists regarded jihad as Islam's instrument for carrying out its ultimate objective by turning all people into believers by the might of sword. It followed, they reasoned, that the existence of a dar al-harb or non-Muslim territory is ultimately outlawed under the Islamic jural order, that the dar al-Islam is permanently under jihad obligation until the dar al-harb is reduced to non-existence.32

Majid Khadduri enunciates the classical doctrine of jihad in these terms:

The jihad may be regarded as a doctrine of permanent war. If the object of Islam was to achieve the universalism of a State and a religion (at least as the Islamic creed was developed by the Muslim publicists), then the jihad naturally meant continuous exertion of power until the whole world was converted to Islam and constituted the Islamic State. 33

Although Khadduri claims that his view represents the classical theory ${ }^{34}$ of Islamic Law, in fact it is mainly based on the idea of Al-Shafi' I. There is indeed no consensus of opinion among classical jurists toward the nature of jihad. Many of them, including most of the Hanafi jurists and Awza i, Malik and many others, were of the view that the dar al-Islam was to resort to war only when the dar al-harb came into conflict with Islam. ${ }^{35}$ Ibn Taymiyah interpreted the jihad to mean a defensive war against unbelievers whenever they threatened Islam. Unbelievers who made no attempt to encroach upon the dar al-Islam, Ibn Taymiyah explained, would not have Islam imposed upon them by force. 36

See Hosny M. Gaber, The Early Islamic State with Special Reference to Evolution of Islamic International LaW 632-750 AD, 133 (1962).

33 Majid Khadduri, International Law, in Law In The Middle East, Vol. 2, 354, (The Middle East Institute, Washington D.C., 1955).

34 Abdul Hamid Abu Sulayman emphatically indicates that: "when writers speak of Muslim Classical theory, they do not speak of the Qur'an or the Sunnah. Rather, they will usually be found referring to the judicial speculations made at the height of Muslim civilization during the high Caliphate, primarily the Abbasi period (750-1100).” See Abdul Hamid Abu Sulayman, Towards an Islamic Theory of International Relations 55 (1994).

35 Abu Hanifa and his disciples, especially Shaybani laid down the rule that a normal state of war existed between Islam and non-Islamic territories; but they made no explicit statements that jihad was a war to be waged against unbelievers solely on account of their disbelieve (Kufr). On the contrary, the early Hanafi jurists seem to have stressed that tolerance should be shown on unbelievers, and advised their Imam to prosecute war only when the inhabitants of the dar al-harb came into conflict with Islam. This was also the position of Awza 'i, Malik and other early jurists; see KHADDURI, THE IsLAmic LAW of NATIONS, supra note 2, at 57-58. It was Shafi'i who first formulated the doctrine that the jihad had for its content the waging of war on unbelievers for their disbelieve; see ISLAMIC JURISPRUDENCE: SHAFI's RisAla 84-86 (Majid Khadduri trans., 1961).

36 Ibn Taymiyah, al-Siyasah al-Shar iyah, 123-4 (1955), quoted in KHADDURI, ISLAMIC LAW of NATIONS, supra note 2, at 59. 


\section{The notion that Jihad is defensive and offensive}

Although early Sunni doctrine was that the military dimension of jihad was only for selfdefense, 37 between the seventh and twelfth centuries, the four major Sunni schools of jurisprudence developed various doctrines of jihad. Most of these doctrines extended jihad to justifiable aggression, something akin to the contemporary doctrine of preemptive self-defecne. 38 The majority of the classical jurists stated jihad as both defensive and offensive. They divided jihad into two main modalities: the 'defensive jihad' and the 'aggressive jihad'. 39

In any case, the aggressive nature of jihad dominated in the books of figh and was established as the classical doctrine of the Islamic law. Nevertheless, the doctrine was postulated at a time when the Islamic state was surrounded by others which are hostile and wanted to annihilate the former. The situation has since fundamentally changed. In the contemporary world, there are a number of Islamic and other States living together peacefully. They adhere to the Charter of the United Nations and numerous other international treaties and conventions. There is no state of war between them. In the context of the geo-political realities of the need for co-existence with non-Islamic nations, the classical concept of the perpetual jihad or state of war becomes outdated and anachronistic.40

\section{Back to Roots: Jihad as Self-Defense}

The main stumbling block for the reconsideration of the classical doctrine is the theory of the so-called "closing of the gate of ijitihad (independent interpretation)", which enshrined taqlid as the order of the day. ${ }^{41}$ It is submitted that the one possible way to overcome this obstacle is for all the Muslim scholars of the present day to seek unanimous consensus on this matter and establish an ijma on the basis of the Qur' an and the Sunnah.

There are a number of modern Muslim scholars who have advocated for the reconsideration of the classical doctrine by going back to the roots - the two primary sources of the Islamic law: the Qur' an and the Sunnah. Al-Ghunaimi, for example, believes that the dualism of dar al-Islam and dar al-harb is an 'Abbasid' perversion that is

\footnotetext{
37 M. Cherif Bassiouni, Evolving Approaches to Jihad: From Self-Defense to Revolutionary and Regime Change Politica, 8 CHI. J. INT'L.L. 119, 135 (2007).

38 Id. at 136.

39 Sherman A. Jackson, Jihad and the Modern World: To Abd. Al-Karim Salabuddin, 7 J. IslAmic L. \& Culture 1, 1516 (2002).

40 WeERAMANTRY, supra note, 3 , at 148 .

41 Sherman A. Jackson, supra note 39, at 7.
} 
unsupportable in terms of the belief and practice of the original Islamic community and that the two terms themselves are alien to the Qur' an and hadith, and so must be recognized as an invention of the later medieval jurists whom al-Ghunaimi labels classicists. 42 It becomes clear from al-Ghunaimi' s analysis that jihad is defensive in character because of the continued aggressiveness of polytheists and that an aggressive jihad finds no basis in true Islamic theory.

'Abdul Hamid' Abu Sulayman, in response to the protagonists of the idea that jihad is an all-out war against unbelievers until the end of time, succinctly explains that:

They took the Qur'anic verses out of context and thus destroyed their significance. The Qur' an and the Sunnah ordered all-out war against the Arab pagans who were always referred to as Mushrikun (idolators or associators). Whenever the Qur' an speaks of these Arabs, it stresses their cruelty, treachery, hypocrisy, greed, savagery, etc. The Arabs who were the subject of these Qur' anic verses were mainly bedouins who continually attacked and persecuted Muslims and betrayed their pledges... Islam developed an attitude of all-out war only against the Adnani bedouins and their Qurayshi leadership in their opposition to Islam.43

Dr. Saba Habachy is of the following view:

In the 8th and 9th centuries, the Islamic City-State of Madinah had expanded beyond expectation and had become a world empire. Islam had to defend its new frontiers and was on the march to conquer hostile peoples. Muslim jurists searched for a justification and they found in the Qur'anic texts about jihad and came up with the distinction between the two Dars. Modern scholars, however, hold that the war envisaged in Divine Revelation was always a defensive and never an offensive war. The Messenger of Allah (Peace be upon him) and his companions were only allowed to fight the unbelievers, ...who had persecuted them and driven them out of their homes in Makkah. 44

The view of Muhammad 'Abduh (1842-1905) from al-Azhar, one of the most prominent Muslim scholars, is that: "the early wars fought by the Companions of the Messenger of Allah (Peace be upon him) were for protecting the call of Islam and saving Muslims from being dominated by aggressors. The Islamic conquests which occurred later were a result of the nature of power and not all of them are valid in Islam" ${ }^{45}$ The Islamic scholars, classified as the modernists, generally maintain that war is permitted to

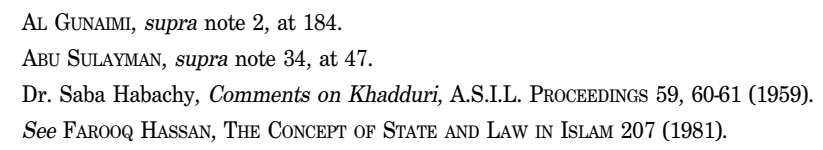


defend the faith, the territorial integrity of the states, to defend the oppressed and persecuted of the world, to protect the honour, dignity and freedom of man, and to preserve peace in the world. 46

\section{The Nature of Self-Defense in Islam}

Islam has great respect for human life and has done everything it possibly can to save and protect human life.47 An injunction of the Holy Qur' an is that: "o Nor slay such life as Allah has made sacred, except for just cause..." 48 'Self-defense' is one of the just causes accepted by Islam. 49

A famous saying of the Messenger of Allah (Peace be upon him) clearly enunciates the excellence and importance of self-defense in Islam:

Whoever fights in defense of his person and is killed, he is a martyr; whoever is killed in defense of his property, is a martyr; whoever fights in defense of his family and is killed, is a martyr; and whoever is killed in the cause of Allah is a martyr. ${ }^{50}$

'Martyrdom' (al-Shahadah) is the noblest religious honour for Muslims. Therefore, this tradition of the Messenger of Allah (Peace be upon him) makes it crystal clear how important the concept of self-defense is in Islam. The tradition recognizes the legitimate right of self-defense to protect one' s life, property, and family, which is the domain of Islamic criminal law.51 It also acknowledges fighting in the cause of Allah, i.e., fighting against persecutors and aggressors in defense of the Faith and to have perpetual freedom for the people to practise Islam, which is the main concern of the present study.

46 Karima Bennoune, Humanitarian Law in Islamic Jurisprudence, 15 Mich. J. INT’L L. 605, 617 (1994).

47 See Al-Qur'an, Surah al -Ma'idah 5: 32 which reads: "if anyone slew a person - unless it be for murder or for spreading mischief in the land - it would be as if he slew the whole people; and if anyone saved a life, it would be as if he saved the lives of the whole people..."

48 Al-Qur'an, Surah al -Furqan 25: 68 in part.

49 Yusur ALI, supra note 28, at 905 n.3128.

50 Abu Dawud, Sunan Abu Dawud, vol. 3, Kitab al-Sunnah, Chapter 1708, Hadith 4754, (Ahmad Hasan trans., 1984).

51 According to Islamic criminal law, there are certain conditions for the exercise of the right of self-defense:

(1) the presence of transgression;

(2) the wrong must have been actually done;

(3) it is not possible to deter the wrong in question otherwise;

(4) the quantum of force used to deter the wrong should be commensurate with the needs to do so.

See Abdul QAdir Qudah Shaheed, 2 Criminal Law of Islam 185-201 (International Islamic Publishers, Karachi 1987); see generally Cherif Bassiouni, The Islamic Crimunal Justice System 185 (1981). 
Islam considers peace as the original state of nature and only in exceptional cases war is permitted. The Qur' an states that it is a check which limits oppression, injustice and transgression.52 Islam prohibits all kinds of warfare except the "jihad," which is the war in the cause of Allah.53 We have already elaborated above that Islam prohibits aggressive war and that the essence of the military aspect of 'jihad' is 'self-defense.' It is necessary now to analyze relevant Qur' anic ayat in more detail and the practice of the Messenger of Allah (Peace be upon him), the two primary sources of the Islamic law, to further fortify the above thesis.

\section{The Holy Qur' an and the Idea of Self-Defense}

As already seen above, although classical Muslim writers treat jihad as a defensive or offensive obligation, almost all of the modern Muslim scholars regard it as a defensive war.54 There are numerous Qur' anic ayat which mention about the peaceful call for Islam. There are also sufficient number of ayat which clearly and unambiguously command the Muslims to fight only those who first fight them or who committed persecution or oppression against them. 55 However, the classical writers quoted some Qur' anic ayat only in part and interpreted them out of the context to support their view that Islam sanctions aggressive war. So as to be able to rebut these misinterpretations, we need to thoroughly examine the ayat quoted by classical writers.

\section{A. The Ayah 2: 193}

The Kifayah claims that fighting was enjoined absolutely at every time and in every place, citing the ayah 2: 193 in part: "And fight them on until there is no more persecution..." 56 In fact the word 'persecution' (fitnah) indicates that the Makkans, as then, were still attacking and torturing the Muslims. Islam's view is that 'persecution is worse than slaughter'. Since the unbelievers of Makkah were the ones who did the persecution, they were obviously on the offensive. The Muslims who repelled the

\footnotetext{
Al-Qur'an, Surah al -Baqarah 2: 251 in part.

See MaUlana Fazlul Karim, supra note 15, at 339-40; MaUlana Muhamiad Ali, supra note 17, at 253.

54 Abu Sulayman, supra note 34, at 47; Mulana FaZlul Karim, supra note 15, at 339; Mahmud Shaltut, supra note 26 , at 51 .

55 Al-Qur'an, Surah al -Baqarah 2: 190, 2: 191, 2: 192, 2: 217; Surah al -Nisa' 4: 75; Surah al -Tawbah 9: 13; Surah al Hajj 22: 39, 22: 40; Surah al -Shura 42: 39.

56 AL GunaIMI, supra note 2, at 144.
} 
persecution and aggression were simply on the defensive. Therefore, the fighting mentioned in the ayah 2: 193 is clearly in 'self-defense.'

This interpretation will be more complete if we read the ayah 2: 193 in the context of the ayat that precede it, i.e., the ayat 2: 190 to 192 . It will be only logical if they are read together.

Fight in the cause of Allah those who fight you, but do not transgress limits; for Allah loveth not transgressors. ${ }^{57}$

And slay them wherever ye catch them, and turn them out from where they turned you out; for persecution is worse than slaughter; but fight them not at the Sacred Mosque, unless they (first) fight you there; but if they fight you slay them. Such is the reward of those who suppress faith. 58

But if they cease, Allah is Oft-Forgiving, Most Merciful.59

And fight them on until there is no more tumult or oppression, and there prevail justice and faith in Allah; but if they cease, let there be no hostility except to those who practice oppression. 60

The ayah 2: 190 is clear, unambiguous and at the same time authoritative. It prescribes that the Muslims are permitted to fight in the cause of Allah 'against those who fight them.' The only rule which can be deduced from this ayah is that war is permitted only in 'self-defense.' Again that portion of the verse makes it clear that a war in self-defense, i.e., to fight against those who first fight the Muslims is a war in the cause of Allah.

To put more emphasis on that principle, the ayah goes on to say that "but do not transgress limits; for Allah loveth not transgressors.' Even in self-defense, Muslims must not transgress the limits imposed by Allah's law. The expression 'Allah loveth not transgressors' is the same as saying that 'Allah loveth not aggressors.' This is the tradition of Allah, Most High. It is beyond all doubt that Allah who hates transgression or aggression of any kind will never permit Muslims to wage an aggressive war.

The ayah 2: 191 is connected with the ayah 2: 190 by the conjunction 'and' : "And slay them wherever ye catch them, and turn them out from where they turned you out, for persecution is worse than slaughter..." Here 'you' refers to the Messenger of Allah 
(Peace be upon him) and the believers and 'they' refers to the unbelievers of Makkah who persecuted the Messenger and the believers until the latter were forced to leave their homes, their property, their relatives and above all, the $K a^{\prime}$ ' $b a h$, and seek refuge in Madinah. Therefore, this ayah also permits a war in 'self-defense' to fight the persecutors and to reclaim the legitimate right of domicile in Makkah. The Qur' an forbids not to fight them in the sacred Mosque, the Ka' bah, because it is a sanctuary where fighting is prohibited. However, even in the Sacred Mosque, if the unbelievers first fight believers, the latter are permitted to exercise 'self-defense.' 61 Again the ayah 2: 193 is connected with the ayah 2: 190 by the conjunction 'and' to specify the aim of fighting which is the suppression of the persecution. Therefore, it by no means permits an aggressive war. There can be no doubt that it also refers to a war in 'self-defense.'

\section{B. The Ayah 2: 216}

Some of the classical writers refer part of the ayah 2: 216 like this: "Fighting is prescribed upon you, and ye dislike it..." If we read the verse only in part and not in the context, the expression "Fighting is prescribed upon you" appears that war is prescribed without any exception and limitation. Such a selective reading is against all the accepted rules of interpretation. In fact the ayah 2: 216 is contained in Surah al -Baqarah which includes the above mentioned ayat 2: 190 to 2: 193, and consequently the ayah 2: 216 undergoes the same logic in interpretation.

\section{The Ayah 9: 5}

The ayah 9: 5 should also be read in the context of the ayat 9: 1 to 9: 13 if we are to understand it in its proper meaning. Some of the important ayat will be quoted below:

A (declaration) of the dissolution of treaty obligations from Allah and His Messenger to those of the Pagans with whom ye have made a treaty- 62

Go ye, then for four months, backwards and forwards, (as you will), throughout the land...63 (But the treaties are) not dissolved with those Pagans with whom ye have entered into alliance and who have not subsequently failed you in anything, nor

See Hamidullah, supra note 2, at 165.

62 Al-Qur'an, Surah al -Tawbah 9:1. The unbelievers frequently made treaties of alliance with the Muslims. The Muslims scrupulously observed their part, but the unbelievers violated their part again and again when it suited them. After some years' experience it became imperative to denounce such treaties altogether. This was done in due form, with four months notice, and a chance was given to those who faithfully observed their pledges, to continue their alliance. Yusur ALI, supra note 28, at 437 n.1246.

63 Al-Qur'an, Surah al -Tawbah 9: 2. The four months refer to the four months of grace. 
aided anyone against you. So fulfil your engagements with them to the end of their term: for Allah loveth the righteous. 64

But when the forbidden months are past, then fight and slay the Pagans wherever ye find them, and seize them, beleaguer them, and lie in wait for them in every stratagem (of war); but if they repent, and establish regular prayers and practise regular charity, then open the way for them: for Allah is Oft-Forgiving, Most Merciful. 65

In a believer they respect not the tie either of kinship or of covenant! It is they who have transgressed all bounds. 66

But if they violate their oaths after their covenant, and taunt you for your faith - fight ye the chiefs of Unfaith for their oaths are nothing to them: that thus they may be restrained.67

Will ye not fight people who violated their oaths, plotted to expel the Messenger, and took the aggressive by being the first (to assault) you? Do ye fear them? Nay, it is Allah whom ye should more justly fear, if ye believe! 68

It is clear from the very first ayah that the foregoing injunctions deal only with "those of the unbelievers with whom ye have made a treaty." The unbelievers could be classified into two categories:

(1) those who violated again and again covenants with the Muslims (when the four months of grace are past they were to be attacked as transgressors); and

(2) those tribes of unbelievers who were on friendly terms with the Muslims, and respected their treaty obligations towards the Muslims (the Muslims are not allowed to fight them and have to fulfil their treaty to the end of its term). ${ }^{69}$

65 Al-Qur'an, Surah al -Tawbah 9: 5. The emphasis is on the first clause: it is only when the four months of grace are past, that the unbelievers who unscrupulously violated their covenants are to be attacked.

66 Al-Qur'an, Surah al -Tawbah 9: 10. Their violations of treaty obligations being set out, it is clear that they were aggressors in the worst possible way.

67 Al-Qur'an, Surah al -Tawbah 9: 12.

68 Al-Qur'an, Surah al -Tawbah 9: 13. Here the Holy Qur'an gives three grounds as justifications for fighting in selfdefense against unbelievers: (1) the disregard of treaties; (2) the plot to discredit the Messenger of Allah (Peace be upon him), and turn him out of Madinah as he had been turned out of Makkah; (3) the aggression taken by the Quraysh in breach of the Treaty of Hudaybiyah.

69 Ibn Ishaq, SiRat Rasul Allah. Alfred Gulllaum(trans.), The Life of Muhamad 212 (1955). 
Therefore, the ayah 9: 5 is obviously conditional by the stipulations of the other verses. In the context of the ayat 9: 1 to 9: 13, the most prominent factor is the repeated condemnation of the violations by the unbelievers of their covenants. The unbelievers against whom the Muslims may wage war are those who committed a serious breach of treaty and thus became aggressors, as is explicitly expressed in the ayah 9: 10: "It is they who are transgressors."

Hence it is unacceptable to maintain that the ayah 9: 5 decrees the absolute right of an aggressive war against all unbelievers of all times. If read in the context, it is beyond reasonable doubt that the ayah only refers to the Arab unbelievers who seriously broke their covenants, plotted against the Messenger of Allah (Peace be upon him), and persecuted the Muslims. The ayah, therefore, permits only a war in the nature of 'selfdefense.'

\section{The Ayah 9:29}

The ayah 9: 29 is also partly quoted by classical writers in a way that obscures the meaning. The ayah, in complete, runs as follows:

Fight those who believe not in Allah nor the Last Day, nor hold that forbidden which hath been forbidden by Allah and His Messenger, nor acknowledge the Religion of Truth, from among the People of the Book, until they pay the jizyah with willing submission, and feel themselves subdue.

The ayah, as is clear from its phraseology, is not directed against all the 'Scriptuaries' (ahl al-kitab) but only towards such of them who commit certain acts expressed in the verse.70 The translation of the ayah by 'Abdullah Yusuf "Ali is: "From among' the People of the Book.71 Thus it is conspicuous that it only refers to "some among' the Scriptuaries. This ayah is a prelude to the ayat referring to the Tabuk expedition which the Muslims were to mobilize against the Byzantines. Thus, the incident of the revelation is relevant only to some of the Scriptuaries, namely, the Byzantines.

Some interpret the ayah as meaning that fighting is to be enjoined against those who do not embrace Islam. This is a misinterpretation because the expression "fight those who believe not in Allah nor the Last Day" is clearly "qualified" by the phrase "from among the People of the Book."

70 AL GUNAIMI, supra note 2, at 171.

71 YUsuf ALI, supra note 28, at 445. 
From the above analysis, we can conclude that it is due to some of the classical writers and commentators that jihad came to be interpreted as a war waged against unbelievers even though they were not the aggressors. But such a doctrine is wholly unauthorized by the Holy Qur' an and can only be extracted therefrom by quoting isolated portions of different ayat, considered apart from the context and the 'special circumstances' under which they were laid down. The above analysis has proved beyond reasonable doubt that no precept is to be found in the Qur' an, which, taken from the context, can justify unprovoked war. War is permissible only in 'self-defense' and in the cause of Allah'; to restore peace and freedom for the worship of Allah.

\section{The Practice of the Messenger of Allah (Peace be upon him)}

We shall now see the practice of the Messenger of Allah (Peace be upon him), on the basis of the decisive battles fought by him in defense of the Faith and the newly born Islamic State, to ascertain how he interpreted the Qur' an, his conduct being the mirror of the Qur'an.

A proper scrutiny of these battles cannot be made without taking into account the great persecution committed by the unbelievers of Makkah (the Quraysh) and the allout hostilities of the entire Arabia against the first believers of Islam. ${ }^{2}$ There were of course a number of battles or skirmishes. However, we have to look at these battles, not as separate wars, but as component parts of a 'single war' between the Arab unbelievers and their confederates on one side and the believers on the other side. Who started this 'war' ? Who were the persecutors and aggressors? And who were the defenders of their Faith and their very existence? The answer appears to be quite clear.

The Messenger of Allah (Peace be upon him) and the first believers of Islam suffered merciless persecution at the hands of the Quraysh for 13 years.73 They were mocked, assaulted, insulted and tortured. The Messenger of Allah (Peace be upon him) had not been given permission to fight. He had simply been ordered to call men to Allah and to endure insult and forgive the ignorant. Persecution was so great that the believers had to choose whether to give up their religion, be maltreated at home, or to flee the country, some to Abyssinia, and others to Madinah. The Quraysh openly treated the Messenger of Allah (Peace be upon him) and the believers as their avowed enemies.

\footnotetext{
72 Majid Alikhan, Muhammad: The Final Messenger 124 (1980)

73 Afzalur Rahman, Muhamiad as a Military Leader 16 (1980).
} 
When the Quraysh became insolent towards Allah, accused His Messenger as lying, and ill-treated and exiled the believers, He gave permission to His Messenger to fight and to protect himself against those who wronged them and treated them badly. ${ }^{74}$ The very first ayah which was sent down to permit believers to fight in 'self-defense' is:

To those against whom war is made, permission is given (to fight), because they were wronged - and verily, Allah is Most Powerful for their aid.75

The next ayah goes on to say:

They are those who have been expelled from their homes in defiance of right - (for no cause) except that they say, 'Our Lord is Allah...' 76

Finally, the Quraysh even plotted to kill the Messenger of Allah (Peace be upon him). When he escaped their murderous plot and migrated to Madinah, they declared him an outlaw. ${ }^{77}$ The believers were forced to leave Makkah and seek refuge in Madinah to be able to practise their Faith freely. But the Quraysh did not let them live in peace and practise their Faith even in Madinah. They sent an ultimatum to Madinah, either to fight and kill or expel the Messenger of Allah (Peace be upon him) or they would attack Madinah.

This is a brief account of the background history of the war between the Arab unbelievers and their confederates on one side and the believers of Islam on the other. All these factors clearly indicate that there had already been a 'state of war' between them and the believers. ${ }^{78}$ The ultimatum to Madinah and the hostile announcement of Abu Jahl, the Makkan leader, amounted to a 'declaration of war' towards Muslim Madinah.79 It is crystal clear that the Messenger of Allah (Peace be upon him) and the believers exercised the 'inherent right of self-defense' against Arab unbelievers and their confederates.

\section{A. The Battle of Badr}

After constituting Madinah as a city-State, the Messenger of Allah (peace be upon him) succeeded in making defensive alliances with neighbouring tribes. He wanted to exert

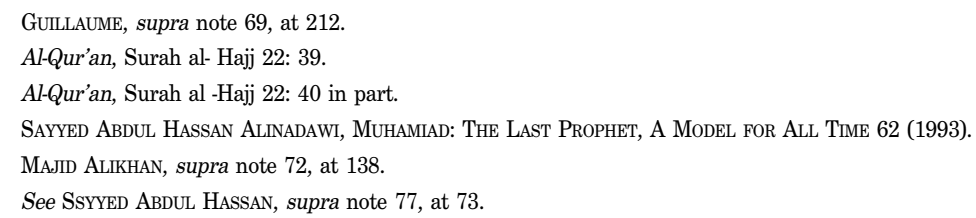


economic pressure on the Makkans. Madinah was on the trading route from Makkah to Syria and Iraq. The Muslims tried to forbid the Makkans not to traverse the Islamic territory. It was permissible on all grounds. The unbelievers of Makkah had confiscated the property of the Muslims who had escaped to Madinah. There was a state of war between the two, and it formed part of the belligerent rights to kill or capture enemy persons and plunder enemy property. And Makkans were utilizing their trade benefits to invade Madinah. 80

In Ramadhan, the second of Hijrah, the Messenger of Allah (Peace be upon him) was informed that Abu Sufyan's caravan was on its way back to Makkah from Syria. They were carrying a vast quantity of wealth and merchandise which was intended to strengthen their logistics to invade Madinah. When the Messenger of Allah (Peace be upon him) heard about this caravan, he decided to attack it because their cavalry would occasionally reach the borders of Madinah. When Abu Sufyan heard that the Messenger of Allah (Peace be upon him) was coming towards him he sent to Makkah for help from the Quraysh.81 The Quraysh army quickly mobilized and set out for Madinah. They were a thousand strong besides a 100 cavalry men. On reaching Badr the Quraysh learnt that the caravan under Abu Sufyan had passed and was then in Makkah safely. ${ }^{82}$ However, they still decided to crush the Muslims. The Muslims successfully defended an army many times larger them theirs.

\section{B. The Battle of Uhud}

To revenge the defeat of Badr, the Quraysh army set out for Madinah in 3 A.H. and the Muslims had to fight in self-defense in the 'Battle of Uhud.' 83

\section{The Battle of Khandaq}

The next important battle is the 'Battle of Khandaq' or 'Battle of the Ditch' which took place in 5 A.H. An alliance was formed between the Quraysh, the Jews and the Ghatafan tribe against the Muslims. The Quraysh gathered four thousand fighters and the Ghatafan six thousand, making ten thousand in all. The Jews agreed to give one year' s harvest of Khaybar to compensate them for their military expenses. 84 The Muslims decided to fortify themselves in Madinah and to defend the city. Their army

\footnotetext{
80 Muhammad Hamidullah, Muhammad Rasulallah: A Concise Survey of the Life and Work of The Founder of ISLAM 68 (1979).

81 SAYYed ABdul HaSsan, supra note 77, at 73.

82 Allama Shibilinu'mani, Sirat-Unnabi 13-14 (1983).

833 SAHIH Muslim, Abdul Hamid SiddiqI (trans.), vol. 3, Kitab al-Jihad Wa'l-Siyar, Chapter 739, Ahadith 4413-4414 (Sh. Muhammad Ashraf, 1980).
} 
numbered less than three thousand and Salman al-Farsi suggested that a ditch should be dug around the city for protection. The Messenger of Allah (Peace be upon him) agreed and thus they defended the large army of the confederates behind the ditch. 85 Therefore the battle of Khandaq was also a clear case of 'self-defense.'

\section{The Battle of Khaybar}

The Battle of Khaybar took place in the 7th year of the Hijrah. Khaybar was the most formidable Jewish stronghold in Arabia. Most of the Jews went into self-exile and settled in Khaybar. Some tribes from Madinah, who violated the Pact with the Messenger of Allah (Peace be upon him), also made it their asylum. After the battle of Khandaq, the Jews again began to plot in co-operation with their allies to invade Madinah. When the Messenger of Allah (Peace be upon him) came to know about the plot, he this time considered it more proper to go to Khaybar in order to stop the Jews from invading Madinah. 86

Indeed this was the first battle in which the Messenger of Allah (Peace be upon him) took the initiative to fight. But it by no means was an aggressive war because the Jews had seriously violated the Pact of alliance with the Muslims and force could be used against such a delinquent tribe or nation. Muhammad Hamidullah regards the battle of Khaybar as an instance of nipping the war in the bud. 87

\section{E. The Conquest of Makkah}

The Mesenger of Allah (Peace be upon him) concluded the Peace Treaty of Hudaybiyah with the Quraysh in 6 A.H. According to the Treaty, the Arab tribes were free to enter into alliance with which party they liked. The Banu Bakr entered into alliance with the Quraysh while the Banu Khuza' ah entered into one with the Messenger of Allah (Peace be upon him). Longstanding hostility existed between the two tribes. 88

Due to the instigation of the Quraysh, the Banu Bakr, one night, attacked the Banu Khuza' ah and killed many of them. Some Quraysh leaders also fought with the Banu Bakr secretly at night. The Banu Khuza' ah took shelter in Makkah but the Banu Bakr did not stop killing Banu Khuza' ah even in the 'Haram,' where blood-shed was forbidden according to time-honoured Arab custom. A deputation of the Khuza' ah

\footnotetext{
Guillaume, supra note 69 , at 450-51.

Muhammad Hamidullah, The Battlefields of the Prophet Muhammad 30-31 (1979).

ALLAMA SHIBILINU'MANI, supra note 82, at 156-9.

Hamidullah, Muslim Conduct of State, supra note 2, at 167.

8 Allama ShibLinu'mani, supra note 82, at 187.
} 
tribe went to Madinah and asked the Messenger of Allah (Peace be Upon Him) for help. The Messenger of Allah (Peace be upon him) offered the Quraysh the chance to redress their offence. Instead of expressing any regrets, they had the audacity to declare the Peace Treaty of Hudaybiyah null and void. 89

The attack of the Khuza' ah, who were the allies of the Messenger of Allah (Peace be upon him), was the same as attacking him and a clear breach of the Peace Treaty. It was a legitimate ground for the Muslims to attack Makkah in self-defense. The Messenger of Allah set out for Makkah in the $8^{\text {th }}$ of Hijrah. However, there was no resistance and the conquest of Makkah was peaceful. Above all, the Messenger of Allah (Peace be upon him) forgave the Quraysh, who had persecuted him and the Muslims for so many years.

\section{F. The Battle of Hunayn}

The war-like tribe of Hawazin was very powerful and they regarded themselves as the greatest tribe after the Quraysh. When the Quraysh submitted to the Messenger of Allah (Peace be upon him), the Hawazin became the undisputed champions of the idolworshippers. The Thaqif were also the same. They were disturbed by the fall of Makkah and noticed a great danger to their religion. They gathered a huge army, set out for Makkah, and encamped in the valley of Hunayn which was about a day and a half s journey from Makkah.90

When the news of the invasion of the Hawazin army reached the Messenger of Allah (Peace be upon him), he set out with the Muslim army. The Hawazin, who occupied the strategic positions in the valley of Hunayn started the attack.91 Therefore, it is obvious that the Muslim army did not invade nor attack the Hawazin territory and that on the contrary the Hawazin initiated the aggression by a huge army and lay in wait to attack the Muslims. The Muslim army set out from Makkah only to meet the Hawazin aggressors on the way. The Hawazin started a surprise attack. Therefore, the battle of Hunayn is again a clear case of 'self-defense.' 92

\section{G. The Expedition of Tabuk}

The Messenger of Allah (Peace be upon him) was informed that the Byzantines

90 Allama ShibILINU'mani, supra note at 82, 206-7; MaJID AlikHan, supra note 72, at 285.

91 SAHIH MusLIM, supra note at 83, Kitab al-Jihad wa'l- Siyar, Chapter 730, Ahadith 4385-92.

92 Hamidullah regards the battle of Hunayn as a 'preventive' war or an anticipatory self-defense according to the modern terminology. See Hamidullah, Muslim Conduct of State, supra note 2, at 167. 
(Romans), under the instructions of the Emperor Heracleus, had collected a huge army and were preparing to invade Arabia. He had no choice but to collect as large a force as he could and march to Tabuk, a place near the frontier of Arabia, quite close to what was then Byzantine territory in the Province of Syria. When the Muslim army arrived at Tabuk, they found that the Byzantine army had been withdrawn. 93 The aim of the Messenger of Allah (Peace be upon him) was to defend Arabia and not to invade Byzantine empire, so he did not pursue them. Therefore, the Tabuk expedition is clearly an action of 'self-defense' to repel a war of aggression of a foreign power. It is the last expedition carried out by the Messenger of Allah (Peace be upon him).

From the above analysis, we can conclude that all the battles fought by the Messenger of Allah (Peace be upon him) throughout his lifetime, except the battle of Khaybar, are obvious cases of the exercise of the inherent right of 'self-defense.' Even the battle of Khaybar, in which the Messenger of Allah (Peace be upon him) initiated the attack, was by no means an aggressive war. It can be said as the continuation of the defensive war of Khandaq to finish the Jews who conspired against the Muslims in Khandaq and to attack those who violated the Pact of alliance. In any case, as has been stated earlier, all these battles are to be regarded as a 'single war' between the Arab unbelievers and their confederates, who persecuted, oppressed, and took the aggressive path from the very beginning, on one side, and the believers of Islam, on the other. It goes without saying that for the believers it was a war fought in 'self-defense.' Therefore, the actual practice of the Messenger of Allah (Peace be upon him) is in complete harmony with the Qur' anic injunctions which only permit 'war in the cause of Allah' and in 'self-defense.'

\section{Kinds of Self-Defense}

Islamic law recognizes self-defense as the natural and legal right of a human being as well as a State. The right of self-defense under the Islamic international law appears to be much wider than that under modern international law. It is not limited to a defense against an aggressive war addressed by a foreign State. It can also be exercised when there is suppression of the freedom of Faith, the freedom of worship, the freedom to invite people to Islam, and transgression of any kind. Before going into detail on the different categories of self-defense, it is, first of all, necessary to clarify the meaning of the expression "to fight in the cause of Allah." 


\section{A. To Fight in the cause of Allah}

The Holy Qur' an in many places commands 'to fight in the cause of Allah' (Qatilu fi sabil Allah). What is the cause of Allah? It is an overwhelming and comprehensive expression. Its meaning has been hinted in the following Qur' anic ayah:

Those who believe fight in the cause of Allah, and those who reject Faith fight in the cause of Evil ...94

The ayah makes it clear that those people who fight for self-glorification or for the exploitation of the weak or for aggression are in fact friends of the Evil, whereas those who fight to curb tyranny and aggression, to eradicate evil from the human society, fight in the cause of Allah.

The cause of Allah is the direct opposite of the cause of Evil. Allah loves justice, righteousness, truthfulness, trustworthiness, faithful observance of covenants, freedom of worship and respect for human rights. Allah hates injustice, deceitfulness, breach of trust, breach of covenants, oppression, persecution and aggression. Therefore, fighting against these evil things can generally be said as fighting in the cause of Allah.

In other words, Allah has commanded the believers what to do and what to abstain from doing in the Holy Qur'an. This is the law of Allah. Fighting for the law of Allah or the word of Allah to become supreme is fighting in the cause of Allah. It is narrated on the authority of 'Abu Musa Ash 'ari that once a man went to the Messenger of Allah (Peace be upon him) and asked: "one man fights for the sake of spoils of war, the second one fights for fame and glory and the third to display his courage and skill; which among them is a fighter in the cause of Allah?" The Messenger of Allah (Peace be upon him) replied: "He who fights with the sole objective that the word of Allah should become supreme is a Mujahid in the cause of Allah." 95

For a devoted Muslim, whatever he does is for Allah. Therefore, if he fights against injustice, it is in the cause of Allah; if he fights against persecution and oppression, it is in the cause of Allah; and if he defends a transgression against his person, family, property, or country, it is in the cause of Allah. In the Holy Qur' an, the injunctions 'to fight in the cause of Allah' can be found in at least seven ayat and it appears that the main ground for the command to fight in the cause of Allah is to resist persecution and oppression. Here are a few examples: 
Fight in the cause of Allah those who fight you but do not transgress limits, for Allah loveth not transgressors. 96

Didst you not turn thy vision to those who abandoned their homes, though they were thousands (in number), for fear of death? ... Then fight in the cause of Allah and know that Allah heareth and knoweth all things. 97

... They said: 'How could we refuse to fight in the cause of Allah, seeing that we were turned out of our homes and our families?' ...98

And why should you not fight in the cause of Allah and of those who, being weak, are ill-treated (and oppressed) ?...99

Those who believed and adopted exile, and fought for the Faith, with their property and their persons, in the cause of Allah ...100

The only conclusion which can be drawn from these Qur' anic injunctions is that fighting in the cause of Allah is always in a defensive nature: in defense of Faith, in defense of persecution, in defense of oppression, etc. Consequently, the war in the cause of Allah is the war in self-defense. It is in accord with the thesis we have already forwarded that 'jihad' is a war in self-defense. And that is why the Messenger of Allah (Peace be upon him) emphatically announced that: "Whoever fights in defense of his person (or his property or his family) and is killed, is a martyr." 101 This is because he resists the oppression of the oppressor and is killed as an oppressed.

\section{B. Self-Defense against Persecution and Oppression}

This is the fundamental and the most important ground for self-defense under the Islamic international law. A number of the Qur' anic injunctions deal with self-defense against persecution and oppression. Some examples are:

Fight in the cause of Allah those who fight you ...102

And fight them on until there is no more tumult and oppression, and there prevail

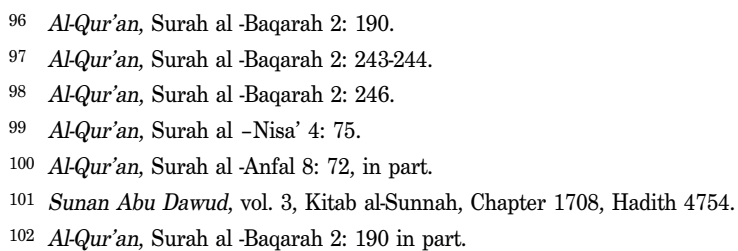


justice and faith in Allah ...103

... graver is it in the sight of Allah to prevent access to the path of Allah, to deny Him,...Tumult and oppression are worse than slaughter... 104

(They are) those who have been expelled from their homes in defiance of right - (for no cause) except that they say, 'Our Lord is Allah.' Did not Allah check one set of people by means of another there would surely have been pulled down monasteries, churches, synagogues, and mosques, in which the name of Allah is commemorated in abundant measure ...105

These ayat clearly permits fighting in self-defense against persecution and oppression. The battles fought by the Messenger of Allah (Peace be upon him) and his Companions are the best examples of this type of self-defense.

It is one of the methods of the Qur' an to give practical examples. Apart from the Qur' anic injunctions enjoining the Messenger of Allah (Peace be upon him) and his Companions to fight in self-defense, there are also two other conspicuous practical examples regarding self-defense against persecution and oppression. The first is based on the Jewish history. It relates to the incident of the Prophet Samuel when the Jews asked him to raise up a king for them to lead them in the 'war of emancipation' from the oppression of the Palestinians.

... 'appoint for us a King, that we may fight in the cause of Allah.' He said: 'Is it not possible, if ye were commanded to fight, that ye will not fight?' They said: 'How could we refuse to fight in the cause of Allah, seeing that we were turned out of our homes and our families?' ...106

The second is the famous history of Pharoah and the Prophet Moses who led the emancipation of the tribe of Israel from the tyrannous rule of Pharoah.107 Thus the Holy Qur' an places special emphasis on oppressed people because oppression is a thing Allah hates most:108

\footnotetext{
103 Al-Qur'an, Surah al -Baqarah 2: 193 in part.

104 Al-Qur'an, Surah al -Baqarah 2: 217 in part.

105 Al-Qur'an, Surah al -Hajj 22: 40 in part.

106 Al-Qur'an, Surah al -Baqarah 2: 246.

107 We can find a number of revelations in the Qur'an about the persecution and oppression of Pharoah on the tribe of Israel. See e.g, Al-Qur' an, Surah al -A'raf 7: 103- 127; Surah al -Qasas 28: 4-5; Surah al -Mu'min 40: 23-25.

108 A hadith of the Messenger of Allah (Peace be upon him) runs: "Beware of the curse of the oppressed as there is no screen between his invocation and Allah”; 3 Sahih al-Bukhari, The Book of Oppressions, Chapter 10, Hadith 628.
} 
Behold! The Curse of Allah is on those who do wrong!109

... For (Allah) loves not those who do wrong. 110

The blame is only against those who oppress men with wrongdoing and insolently transgress beyond bounds through the land, defying right and justice.111

Therefore, if there is persecution in the sense of suppression of religion and Faith or oppression in the sense of injustice and grave violations of fundamental human rights, 112 the Muslims are bound to resist it with the use of force in self-defense.

\section{Self-Defense against Aggression of a Foreign State}

It is in the Islamic law that the term 'aggression' was first employed. Thirteen centuries later, i.e., only at the beginning of the twentieth century, aggression as a term was introduced into the contemporary international law. Aggression is evil and against the moral and legal philosophy of the law of Allah. For this reason, the Qur' an vividly clarifies its basic attitudes towards aggression and states that: "Allah loveth not transgressors." 113 That is why Muslims are prohibited from waging an aggressive war. As Islam never tolerates aggression, Muslims are bound to repel an aggressive war waged by a foreign State. The Qur' an says:

To those against whom war is made, permission is given (to fight), because they are wronged - and verily, Allah is most powerful for their aid.114

Fight in the cause of Allah those who fight you ... And slay them wherever ye catch them, and turn them out from where they have turned you out ...115

The following main principles of self-defense against aggression can be deduced from these ayat of the Qur' an:

1. the Islamic State can use force in self-defense against a State that waged an aggressive war;

2. A war in self-defense is a just war and a war in the cause of Allah. The fighters are blessed and Allah will surely help them;

\footnotetext{
109 Al-Qur'an, Surah Hud 11: 18 in part.

110 Al-Qur'an, Surah al -Shura 42: 40 in part.

111 Al-Qur'an, Surah al -Shura 42: 42 in part.

112 See The Universal Islamic Declaration of Human Rights, Islamic Council, 19 September, 1981. For the text, see Farhad Malekian, The Concept of Islamic International Criminal LaW 183-191 (1994).

113 Al-Qur'an, Surah al -Baqarah 2: 190 in part.

114 Al-Qur'an, Surah al -Hajj 22: 39.

115 Al-Qur'an, Surah al -Baqarah 2: 190-191 in part.
} 
3. The Muslims should fight and try to regain the lands from where they have been driven out;

4. They must drive out the enemies from places from where they were driven out.

The last two principles are concerned with the principle of proportionality to be observed in exercising the right of self-defense.

\section{Self-Defense in Support of a State that is the Victim of an Aggressive War}

The faithful observance of treaties is one of the basic tenets of the Islamic international law. 116 Therefore, if a State with which the Islamic State has a treaty of alliance has become a victim of aggression, the Islamic State is bound to help it in resisting the aggressor State. This can be well illustrated by a practice of the Messenger of Allah (Peace be upon him). The Banu Khuza' ah had a mutual alliance with the Messenger of Allah (Peace be upon him). They were attacked by the Banu Bakr with the help of the Quraysh. In answer to their request for help, the Messenger of Allah (Peace be upon him) set out for Makkah which led to its conquest.117 Even though there is no treaty of alliance between the Islamic State and the victim State, the former should still help the latter in self-defense against the aggressor. This assistance is given to the victim State in order to restore peace and justice as commanded by the law of Allah. The Muslims cannot neglect a state of injustice as the best Muslims are those who enjoin what is right and forbid what is wrong:

Let there arise out of you a band of people inviting to all that is good, enjoining what is right and forbidding what is wrong ...118

Ye are the best of peoples, evolved for mankind, enjoining what is right, forbidding what is wrong, and believing in Allah ...119

\section{E. Self-Defense for the Assistance of Persecuted Muslims}

The important issue to consider here is whether the Islamic state is bound to help the Muslims suffering persecution and oppression under a non-Muslim government. According to the Qur' an each case must be decided on its own merits:

\footnotetext{
116 See Al-Qur'an, Surah al -Nahl 16: 91; Surah al -Mu'minun 23: 8,11.

117 Allama ShibIlinu'Mani, supra note 82, at 187-8.

118 Al-Qur'an, Surah Al 'Imran 3: 104 in part.

119 Al-Qur'an, Surah Al 'Imran 3: 110 in part.
} 
... As to those who believed but came not into exile; ye owe no duty of protection to them until they come into exile; but if they seek your aid in religion, it is your duty to help them, except against a people with whom ye have a treaty of mutual alliance ...120

And why should you not fight in the cause of Allah and of those who, being weak, are ill-treated (and oppressed)? - men, women, and children, whose cry is: 'Our Lord ! Rescue us from this town, whose people are oppressors; and raise for us from Thee one who will protect ; and raise for us from thee one who will help!' 121

According to the first ayah, if there is persecution and oppression on account of religion, the believers are to migrate to other places where they can live in peace and practise their Faith. For those who were not strong enough to suffer exile and make the personal sacrifices, they could not reasonably ask from the Islamic State for political or military assistance or protection. If they ask assistance in matters of religion, the Islamic State has to help them unless there is a treaty of mutual alliance between it and the State of residence of the persecuted Muslims.

The second ayah appears to permit fighting for the sake of those Muslims who, being weak, are ill-treated and persecuted. Hamidullah names it 'sympathetic war', but admits that he could not find a case of this kind in the life of the Messenger of Allah (Peace be upon him).122 In fact, the ayah refers to those believers who stayed behind in Makkah after Hijrah. Persecution was redoubled for them. However in the $6^{\text {th }}$ year of Hijrah, the Peace Treaty of Hudaybiyah was concluded between the Messenger of Allah (Peace be upon him) and the Makkans. Under the terms of the Treaty, the Muslims who fled to Madinah to escape the tortures, were to be returned back to Makkah.123 Although the treaty seemed to be unfair to the Muslims, it in fact gave a real victory. 124 Eventually, the cry for a protector and helper was answered when the Messenger of Allah (Peace be upon him) brought freedom and peace to Makkah again in 8 A.H.

\footnotetext{
120 Al-Qur'an, Surah al -Anfal 8: 72 in part.

121 Al Qur'an, Surah al -Nisa' 4: 75.

122 Hamidullah, Muslim Conduct of State, supra note 2, at 168.

123 SAHIH MusLIM, supra note 83, Kitab al-Jihad Wa'l-Siyar, Chapter 736, Ahadith 4401-4403.

124 Al-Qur'an, Surah al -Fath 48: 1.
} 


\section{Essential Conditions of Self-Defense}

According to Islamic law, self-defense is the inherent right of a human being, a people, or a State. This right has been established in Islamic law since the early time of its revelation. In order for the right of self-defense to be lawful, the following conditions need to be satisfied:

(1) There must be a transgression in the sense of persecution or oppression against Muslims or an aggression against a State;

(2) The principle of proportionality must be observed;

(3) Humanitarian principles must be respected.

These three essential conditions of the right of self-defense will be elaborated in turn below.

\section{A. The Presence of Transgression}

This is the first and most important condition for the right of self-defense to be lawful. There must be a transgression which may be either a persecution or oppression against Muslims or an aggression against a State. The essence of self-defense under Islamic law is that one may defend a transgression against oneself or against other persons. In other words, self-defense may be private defense or defense of other people.125 Consequently, Muslims may defend themselves against persecution or oppression of their own Government that practises tyranny, or the Islamic State may help the Muslims suffering persecution under a non-Muslim Government. Likewise, the Islamic State may exercise self-defense against a foreign State which invades its territory and may also come to the assistance of a State which has become a victim of armed aggression.

\section{B. Principle of Proportionality}

The second essential condition of self-defense is that 'the quantum of force used to deter the transgression must be commensurate with the need to do so.' This is known as the 'principle of proportionality' which is one of the most fundamental concepts of Islamic law. The principle of proportionality requires that no more force has to be used than is

125 ABDUL QADIR, supra note 51, at 183. Although this is based on the criminal law aspect, it is a fundamental principle of Shariah and by analogy we can apply this principle to self-defense under International law as well. 
necessary for the purpose. There must be proportionality between the means chosen and the end in view.

Therefore, according to Islamic law a war should not be made unlimited. When exercising the right of self-defense, the defensive measures must not exceed the harm addressed by the aggressor. The Qur' an commands: "Fight in the cause of Allah those who fight you, but do not transgress limits: for Allah loveth not transgressors." 126 If the force used in self-defense exceeds the limit of necessity, such an act would cease to be self-defense and assumes the character of 'transgression' itself.

From the Qur' anic injunction “....and turn them out from where they have been turned you out..." 127 we can deduce the rule that if the aggressor State has occupied the territory of the Islamic State, it is clearly within the law of proportionality that the Islamic State may fight the aggressor until they have been driven out from that territory.

\section{Humanitarian Principles}

Islamic international law places great emphasis on the conduct of war and the humane treatment of the enemy combatants. It is a cardinal rule of Islamic law that combatants are to strictly observe the 'humanitarian law.' It means that since more than 1400 years ago, Islam has introduced the 'international humanitarian law' 128 which has come to be recognized as a legal concept in contemporary international law only in the twentieth century. Self-defense is no exception and humanitarian principles are to be strictly observed.

Whenever sending an expedition against an aggressor tribe, the Messenger of Allah (Peace be upon him) used to give the following injunction to the commander: "Do not kill the very old nor the infants nor the minors nor the women folk. Do not cheat. Do not break trust." 129 The first Khalifah' Abu Bakr, following the Messenger of Allah (Peace be upon him), ordered his commander:

O Yezid, ... when you meet your enemies show yourself like men and do not turn your backs and if you gain victory, kill not little children, nor old people, nor women. Destroy no palm trees, nor burn any fields of corn. Cut down no fruit trees, nor do any mischief to cattle ... as you go on, you will find some religious persons that live retired in monasteries, ... Let them alone, and neither kill them nor destroy their monasteries. 130

\footnotetext{
126 Al-Qur'an, Surah al -Baqarah 2: 190.

127 Al-Qur'an, Surah al -Baqarah 2: 191 in part.

128 WEERAMANTRY, supra note 3, at 134-5.

129 SAHIH MusLIM, supra note at 83, Kitab al-Jihad Wa'l-Siyar, Chapter 705, Hadith 4294; Sunan Abu Dawud, Kitab alJihad, Chapter 936, Ahadith 2606-08.

130 Syed AmeEr Ali, The SPIRIT of ISLAM 85 (1946).
} 
Islam has purified even war of all its cruelty and horrors. Even though it is a war in self-defense, Islamic law enjoins the Muslims to ever keep in mind the humanitarian principles.

\section{Self-Defense under Islamic and Contemporary International Law: A Comparison}

A comparison made on the basis of the three requirements of lawful self-defense under Islamic international law clearly demonstrates that there are similarities as well as differences between the two systems of law.

\section{A. The Presence of Transgression}

First of all, in respect of the raison d' etre of self-defense, contemporary international law requires that legitimate self-defense can be exercised only when there is an 'armed attack against a State. This is based on the restrictive interpretation of Article 51 of the United Nations Charter.131 The United Nations Charter, in speaking of the use of armed force, employs different terms: the 'use of force,' 132 'act of aggression,' 133 and 'armed attack.' 134 Although their meanings overlap somewhat with one another, they are not completely identical.135 It is of importance to note that Article 51 does not use the term 'use of force' but the much narrower concept of 'armed attack.' 136 In the Nicaragua case, the World Court observed that "it is necessary to distinguish the gravest forms of the use of force (those constituting an armed attack) from other less grave forms." 137 In that case, the Court defines 'armed attack' to include: action by regular armed forces across an international border; and the sending by or on behalf of a State of armed bands, groups, irregulars or mercenaries, which carry out acts of armed forces against another State of such a gravity as to amount to an actual armed attack conducted by regular armed forces. The Court acknowledges that mere 'frontier incidents' may not

\footnotetext{
131 Louis Henkin, Force, Intervention, and Neutrality in Contemporary International Law, ASIL ProcEEDINGS, 147, 151 (1961).

132 U.N. CHARTER, art. 2(4)

133 Id. at art. 39.

134 Id. at art. 51.

135 Rein Mullerson, Self-Defense in the Contemporary World, in Damrosch \& ScheFfer (ed.), LaW and Force IN THE New International ORder 13, 16 (1991).

136 Kelsen, The LaW of the United Nations 498 (1950).

137 Military and Paramilitary Activities in and against Nicaragua (Nicar. v U.S.) 1986 I.C.J. 14, at 101, para. 191.
} 
amount to armed attack.138

However, according to Islamic international law, the raison d'etre of self-defense appears to be much wider. It is not limited to an armed attack. Although an armed attack or an aggression against a State is a legitimate ground for self-defense under Islamic international law, it is not the only ground. If there is persecution in the sense of suppression of religion and Faith or oppression in the sense of grave violations of fundamental human rights, Muslims may wage war until there is no more persecution or oppression.

According to modern international law, only States can exercise the right of selfdefense. However, under Islamic international law, not only States but also the persecuted or oppressed people can also exercise the right of self-defense. Islamic international law recognizes 'the people' or 'individual human beings' as subjects of international law. 139 From this, we can clearly see the advancement of Islamic international law in that in modern international law, the attempt to recognize individuals as full-fledged subjects of international law has not yet been successful.140

A similarity is that both under Islamic and contemporary international law, selfdefense may be either individual or collective.141

\section{B. Proportionality}

As far as the principle of proportionality is concerned, the most-striking injunction of the Holy Qur' an reads: "Fight in the cause of Allah those who fight you, but do not transgress limits: for Allah loveth not transgressors." 142 The requirement of 'proportionality' under Islamic international law is in harmony with modern international law according to which 'necessity' and 'proportionality' are the two basic elements of self-defense. It is a rule of general international law that the defensive action must be commensurate with and in proportion to the armed attack which gave rise to the exercise of the right of self-defense. 143 The formula used by Webster in relation to the Caroline incident has attracted writers by virtue of his insistence that selfdefense must involve: "nothing unreasonable or excessive; since the act, justified by the necessity of self-defense, must be limited by that necessity, and kept clearly within it." 144

\footnotetext{
138 id. at 103-104, para. 195.

139 AL-Ghunaimi, supra note 2, at 127-28.

140 Abdul Ghafur Hamid \& Khin Maung Sein, Public International LaW: A Practical Aproach 95-97(2d ed. 2007).

141 See U.N. CHARTER art. 51.

142 Al-Qur'an, Surah al -Baqarah 2: 190.

143 Jime'nez de Are'chaga, General Course in Public International Law, 9, 159 Rcuell Des CouRs (1978).

14451 British Parliamentary Papers 1843; 29 British Foreign State Papers 1129.
} 


\section{Humanitarian Principles}

To observe humanitarian principles is one of the essential requirements of self-defense under Islamic international law. In the same vein, it is to be noted that the 1949 Geneva Conventions Protecting the Victims of War and the 1977 Additional Protocols, reflecting modern international humanitarian law, are applicable to both parties to an armed conflict, whether they use force in violation of international law or in the exercise of the legitimate right of self-defense. 145

Therefore, the law relating to self-defense under Islamic international law appears to coincide in many respects with that of contemporary international law. However, there is a major difference. According to Islamic international law, not only States but the persecuted or oppressed people also can exercise the right of self-defense. It is a legitimate self-defense not only to fend off an aggressive war launched by a foreign state, but to take up arms in self-defense if there is persecution in the sense of suppression of religion and Faith or oppression in the sense of grave violations of fundamental human rights, until there is no more persecution or oppression. This is the very essence of 'jihad,' the war in the cause of Allah. It is also the most characteristic pattern of a war in self-defense under Islamic international law.

\section{Conclusion}

It is the view of the classical jurists that Jihad is defensive as well as aggressive. A careful scrutiny of the Qura' nic ayat quoted by the classical jurists, not in isolation but in the context, leads to the conclusion that the Qur' an never permits an aggressive war. This is the position of the Qur' an, the first primary source of Islamic law. The Sunnah, the second primary source, also produces the same answer: the Messenger of Allah (Peace be upon him) never fought an aggressive war. All the battles fought by the Messenger of Allah (Peace be upon him) were in the nature of self-defense, against persecutors, oppressors and violators of mutual alliance. The practice of the Messenger of Allah (Peace be upon him) is in complete accord with the Qur' an. The Qur' an and the Sunnah very clearly demonstrate that 'jihad' is never meant to be an aggressive war and that it

145 See Common Article 2 of Geneva Convention (I) for the Amelioration of the Condition of the Wounded and Sick in Armed Forces in the Field (1949), 6 UST 3114 (1956); Geneva Convention (II) for the Amelioration of the Condition of the Wounded, Sick and Shipwrecked Members of Armed Forces at Sea (1949), 6 UST 3217 (1956); Geneva Convention (III) relative to the Treatment of Prisoners of War (1949), 6 UST 3316 (1956); Geneva Convention (IV) relative to the Protection of Civilian Persons in Time of War (1949), 6 UST 3516 (1956). 
only refers to a war in 'self-defense.'

Islam accepts self-defense as an inherent right both for human beings and States. Islam not only permits self-defense but also encourages it and prescribes it as obligatory in most cases. Allah loves those who are righteous, courageous and who resist oppression and injustice. Allah dislikes cowardice:

And those who, when an oppressive wrong is inflicted on them, (are not cowed but) help and defend themselves. 146

Will ye not fight people who violated their oaths, plotted to expel the Messenger, and took the aggressive by being the first (to assault) you? Do ye fear them? Nay, it is Allah Whom ye should more justly fear, if you believe!147

According to Islamic international law, one may defend a transgression against oneself or against others. The right of self-defense can be exercised either as a private defense or as assistance to a victim of transgression. 148 A distinctive feature of Islamic international law is that the right of self-defense is not only for States. The persecuted or the oppressed people can also exercise self-defense against a tyrannical ruler, an oppressive government or an aggressive State. This is very much akin to the right of self-determination of peoples.

Compared to that of contemporary international law, the concept of self-defense under Islamic international law puts more emphasis on 'humanity' rather than on State 'sovereignty.' It lays more stress on persecuted human beings and oppressed people. It asserts more concern on humane treatment of combatants, prisoners of war and noncombatants. 149 It is more humanistic. It has a strong moral and ethical foundation. Due to lack of strong moral and ethical foundation in contemporary international law, States tend to abuse the right of self-defense. Stronger States look for loopholes in the law and use force to invade or intervene in the affairs of weaker States under the pretext of selfdefense. The Islamic concept of self-defense can to some extent help to solve these problems of contemporary international law.

We may, therefore, fairly conclude that Islamic international law can contribute much to the present world order and can provide a moral basis of rules for controlling the conduct of States. It can also help strengthen the core principle of the United

\footnotetext{
146 Al-Qur'an, Surah al -Shura 42: 39. [Emphasis added]

147 Al-Qur'an, Surah al -Tawbah 9: 13. [Emphasis added]

148 "The Messenger of Allah (Peace be upon him) ordered us to do seven things and prohibited us from doing seven things. The seven things ordered to do are: ...(5) to help the oppressed; ..." SAHIH AL-BukHARI, supra note 29, vol. 3, The Book of Oppressions, Chapter 6, Hadith 625. [Emphasis added]

149 Syed AMEer ALI, supra note 130, at 85; see also WeERAMANTRY, supra note 3, at 135.
} 
Nations: the prohibition of the use of force and the principle of self-determination. The modern international law, in its recent development to meet the needs of an expanding world community, should rely on sources of diverse systems of law, including Islamic and not only Western sources. 